\title{
Managing ICT skills profiles
}

\author{
Anneke Hacquebard, Steven Dijkxhoorn \& Anita Erkelens \\ Consultancy and Research Bureau for Informatics and Education, Hummelo, The Netherlands
}

anneke.hacquebard@grip-project.nl; info@grip-project.nl; www.grip-project.nl

Abstract: Human skills and knowledge will be the main economic resources in a Knowledge Society. Therefore parties involved have a need to exchange information about quality and content of knowledge and skills resources. The development of a protocol for communication about skills and knowledge requires a strong international commitment, cooperation and effort on research and development, e.g. on text analysis, modelling, structuring and unified classification schemes for main domains of knowledge. As an example, ICT professionals from all over the world have identified the need for a generic description of ICT skills and knowledge. Because of the great variety in definitions, terminology and conceptual constructs, ambiguity and misunderstandings occur while trying to connect national and international educational and professional descriptions of ICT skills and knowledge. As far as we have observed, nobody has succeeded in defining such a global standard. However, it does not seem to be possible to develop one generic standard for ICT skills and knowledge either on a national scale, on the scale of an international region or on a global scale. This is based on the notion that every description of ICT skills and knowledge has its own professional, social and cultural background and stands in its own rights. A new approach is needed, such as the development and application of a referential framework and tools. A recent initiative is the development of GRIP (Generic Referential ICT Profiles), a method presented as a "common language" approach, to be used to characterise, compare and analyse existing ICT skills profiles. GRIP can be used for different purposes and with different levels of detail. This approach, originally meant for ICT profiles, seems to have a broad range of application in other domains.

Key words: ICT profile, ICT referential framework, ICT skills, ICT standards 


\section{BUCHAREST DECLARATION}

On November 9, 2002, in preparation for the World Summit on the Information Society in Geneva, the Pan European Regional Ministerial Conference launched the "Bucharest declaration" on the Information Society (The Bucharest Declaration 2002). This declaration is based on seven principles and covers four themes. At least two of the themes are closely related to the management of ICT skills:

- E-Business: More

Competitiveness and Better Jobs

- E-learning and E-

Education: Empowering people.

E-Business: More Competitiveness and Better Jobs

Enterprises, both large and small, can use ICTs to foster innovation, realise gains in productivity, reduce transaction costs and benefit from network externalities. In support of this process, Governments need to stimulate, through the adoption of an enabling environment services, regulatory framework for the promotion of private investment applications and content, based on a widely available broadband infrastructure, and foster public - private partnerships. Use of digital technologies can enhance the role of enterprises in promoting entrepreneurship, the accumulation of knowledge, the upgrading of skills, and thereby increasing productivity, incomes and jobs and promoting qualitative improvement of working life. Special attention should be given to small and medium enterprises both as beneficiaries and promoters of e-business.

Figure 1. Bucharest declaration

With respect to both themes we here focus on the enhancement of the accumulation of knowledge, the upgrading of skills and access to knowledge as an essential tool in economic, cultural and social development. People's knowledge and skills, often referred to as human capital, are of great importance for economy and culture. In the Information Society, or Knowledge Society, skills and knowledge are in continuous demand by business, governments, formal and non formal education and, last but not least, by individuals themselves.

E-learning and E-Education: Empowering people E-learning is about development of skills to access knowledge, which addresses numerous issues such as local content, multi-lingual and cultural diversity and intellectual property rights. Access to knowledge is an essential tool in economic, cultural and social development. The potential exists for all those still outside the reach of the formal educational system to be offered education and information tailored to their need and culture. Education empowers people to overcome poverty, therefore e-learning is one of the most important issues in the bridging of the digital divide.

Figure 2. Bucharest Declaration

All parties involved have to manage phenomena like:

- Constantly keeping record of people's acquired skills and knowledge;

- Frequent changes in the workforce because of a greater mobility of people and business; 
- Encouragement of people, employees and employers to enhance skills and knowledge.

\begin{tabular}{|c|c|c|c|c|c|}
\hline Professionalism & Domains & $\begin{array}{l}\text { ICT } \\
\text { knowledge } \\
\text { and skills }\end{array}$ & $\begin{array}{l}\text { Other domain } \\
\text { knowledge } \\
\text { and skills }\end{array}$ & $\begin{array}{l}\text { Personal } \\
\text { quality }\end{array}$ & $\begin{array}{l}\text { Personal } \\
\text { attitude }\end{array}$ \\
\hline $\begin{array}{l}\text { "Non-I-professionals } \\
\text { using ready made I- } \\
\text { technology or I- } \\
\text { applications in their } \\
\text { work." }\end{array}$ & ICT-user & Practical & $\begin{array}{l}\text { Any } \\
\text { All levels }\end{array}$ & \multirow{3}{*}{\multicolumn{2}{|c|}{$\begin{array}{l}\text { Depending on the working } \\
\text { environment }\end{array}$}} \\
\hline $\begin{array}{l}\text { "Non-I-professionals } \\
\text { applying I- } \\
\text { knowledge and I- } \\
\text { skills in areas } \\
\text { different from } \\
\text { informatics" }\end{array}$ & $\begin{array}{l}\text { ICT- } \\
\text { applier }\end{array}$ & Perception & $\begin{array}{l}\text { Any } \\
\text { Specialist, } \\
\text { Conceptual }\end{array}$ & & \\
\hline $\begin{array}{l}\text { "I-professionals } \\
\text { working in the field } \\
\text { of informatics (note } \\
\text { that the field of } \\
\text { informatics is broad } \\
\text { with diffuse } \\
\text { boundaries with } \\
\text { other disciplines)". }\end{array}$ & $\begin{array}{l}\text { ICT- } \\
\text { worker }\end{array}$ & $\begin{array}{l}\text { Specialist } \\
\text { Conceptual }\end{array}$ & $\begin{array}{l}\text { Any } \\
\text { Perception }\end{array}$ & & \\
\hline
\end{tabular}

Table 1. Skills and knowledge matrix

Because of the large number of people involved, the kaleidoscope of educational and practical backgrounds, the variety in data about peoples' skills and knowledge, the dynamics in the development of skills and knowledge, the large amount of data, the managing of skills and knowledge is a rather complex matter. Also complexity and ambiguity of educational levels and of descriptions of skills and knowledge cause language confusion. Communication and development of understanding demand a "common language" to enable the exchange of information.

\section{ICT SKILLS}

The term 'skills' is used as a generic name to describe a person's ability to fulfil tasks and to perform roles in a particular context, usually the working environment.

Skills are part of a more generic description of a person's abilities in terms of competencies. A competency is a description of a person's knowledge, skills, qualities and attitudes that are necessary to fulfil a task in a working environment. As working environments and professionals show 
great differences, skills should be categorised by level of professionalism and domain (Mulder, F. \& T.J. van Weert 2000). See Table 1.

Levels of professionalism are related to educational levels and levels of informal learning. Managing ICT skills in an organisation, requires a decision about the cell or cells of the "skills and knowledge matrix" to be described, to be understood or to be discussed. The matrix also facilitates a generic approach for detailing a set of profiles; in this case the matrix is used

A profile is a pattern of demands and expectations a person has to meet to be able to function in a working environment.

Figure 3. Profile definition as criterion for categorisation of skills.

Skills and knowledge descriptions concerning specific tasks or jobs are usually combined in job profiles. Educational profiles explain the skills and knowledge of graduates.

Let us take 'managing ICT' skills as an example and look at this example from a personal, an educational and a company/organisational perspective.

\section{Personal perspective}

- keeping up with professional development

- working on personal quality and personal attitude.

- to keep track of personal development, portfolios may be used. Prerequisites for this are that the portfolio has already been created during higher or vocational education and that the person is able to maintain the portfolio during his or her working life.

\section{Educational perspective}

- flexible assessment procedures, taking into account student quality and competency, acquired by formal and informal learning;

- facilities to build student's portfolios;

- getting used to the idea that the portfolio belongs to the student;

- facilities for the maintenance and long term availability of portfolios. This requires a long term vision, a guarantee that portfolio sites, portfolio databases or some other information system are long lasting. The mobility of the workforce and the scale of the data to be maintained demand international cooperation to find solutions so that lifelong availability can be guaranteed.

\section{Company and organisational perspective}

- Implementation of competence management systems

- This is a way to manage competencies of personnel, to get to know for what tasks and roles they are employable, what their educational needs 
are, in order to follow career paths. For the people involved competence management systems offer a clear view on their capabilities, on how to handle ambitions and on planning for reaching personal goals and objectives.

To meet the goals stated in the Bucharest declaration and other declarations there is a need to manage ICT skills and knowledge on the level of persons, education, companies and organisations; this implies more precise definitions of the specific skills and knowledge required.

\section{PROTOCOL FOR COMMUNICATION}

To be able to manage ICT skills and knowledge, parties involved should be able to understand and overview the respective skills profiles and job profiles or, in other words, the quality of persons. Attempts to make quick and simple overviews of, for example, the ten leading profile documents, deadlock in differences of approaches.

ICT professionals from all over the world have been asking for a generic description of ICT skills and knowledge. For instance, during the Working Conference Meeting Global IT Skills Needs - the Role of Professionalism, 35 specialists from 14 countries, discussed the need of a standard or referential standard (IFIP OECD WITSA Joint Working Conference Meeting Global IT Skills Needs - the Role of Professionalism October 25th -27 th 2002). One of the conclusions of the conference was: "develop a high level reference model covering groups including IT professionals, IT practitioners and others, to identify the differences in obligations associated with different types of work; to assist the closer matching of employer requirements with educational provision".

Management of skills and knowledge is not only of interest to the ICT domain. There is an urgency to deal with the complexity of knowledge and skills because of its spin-off to industry, education and society. As far as we can see, nobody has been able to define an accepted (global) standard for ICT skills. Experience tells that it is not possible to develop one generic standard for ICT skills and knowledge, either on a national, international or a global scale. Because of the great variety and ambiguity in definitions, terminology and conceptual constructs misunderstandings and deadlocks occur while trying to construct sound overviews of various descriptions of ICT skills and knowledge. 


\section{REFERENTIAL FRAMEWORK}

Communication about the content of ICT skills and about knowledge needs some "vehicle": a framework or a common language approach.

It seems attractive to use an existing set of profiles as a standard or as a framework, but experience shows that one profile model cannot serve "all" existing profiles because of differences in levels, goals, structure and

A profile model is a coherent structure, serving as a basis for the description of a set of profiles.

Figure 4. Profile model definition terminology.

Looking at the skills and knowledge matrix, we notice differences in the mastering of skills and knowledge (practical, perception, conceptual). It is unlikely that one of the existing profile models covers all these areas. It can be considered to use different models for different levels of mastering. This approach carries the risk that it will lead to several sub-standards, existing next to one another, and even worse, with inevitable overlap. As barriers between formal and informal learning diminish, the use of different standards may create confusion.

The choice for a particular standard usually does not meet all the local requirements, opinions and goals. Therefore the use of an existing profile model and the profiles belonging to it, as a standard for "all" profiles, will not solve the problem of diversity and ambiguity. It is better not to focus on just one model serving as a standard, but to look for another solution. And also: existing profile models have not been not build as referential model and will not meet the requirements of a referential model.

By using an independent referential framework - instead of one of the existing profile models - as an "umbrella" a lot of problems can be solved. Such a framework is not available; it has to be newly designed and built.

\section{REQUIREMENTS FOR A REFERENTIAL FRAMEWORK}

What functions should the framework have? A framework is an instrument to link and clarify the main issues of existing and new models describing ICT skills on issues like: content, terminology, skills levels, educational level, competency, tasks and roles, target groups, actor, etc.

Who are supposed to use the referential framework? The existing ambiguity, ordered chaos of models, is a concern of international organisations, governments, employer organisations, employers, employee organisations, educational institutions on all levels, international and 
national professional organisations, parties involved in formal and non formal learning etc. The great variety of users of the framework makes necessary a detailed research on the way those parties want to use it, the tools needed and to (re)define and refine the requirements.

What are the requirements for a referential framework? A framework should be transparent, not too complicated for quick use, offer more advanced (may be inevitably more complex) features for detailed research. A framework has to be clear about its own descriptive terminology, structure and operation instructions. The framework should offer a guideline for building, rebuilding and maintaining of profiles and profile models. The framework should offer a way to map profiles, in order to be able to compare mappings of profiles' content from different origin and different architecture.

What kind of tools are needed? Advanced digital tools have to be developed to support the process of analysis. A huge amount of data has to be handled, text analyses have to be performed and statistics have to be derived. To facilitate reference and distribution of results, easy to use tools for users have to be available. Please note that the development of a referential framework does not imply the development of a new profile model or a new set of profiles.

An independent referential framework:

- does not contain profile descriptions;

- offers an unified approach to:

- analyse profile model structures and terminology used;

- categorise profile models and profiles;

- independently maps profiles content onto domains of knowledge and personal behaviour;

- is a basis for:

- benchmarking or comparing profiles and profile models of different origin and different architecture;

- maintenance and review of existing profiles and profile models;

- a unified guideline for development of profiles and profile models.

As an advantage of a referential framework for benchmarking and comparison, existing profiles do not have to be changed. Another reason to keep existing models alive is that people and organisation usually have very good reasons for the use of "their" terminology and "their" profiles. For many good reasons they are not very willing to drop their models and profile descriptions.

In due course, as a spin-off, while the framework approach gets acknowledgment and achieves a status generally accepted, the referential 
framework can encourage unity of terminology and unity of structures of profile models.

\section{GRIP: GENERIC REFERENTIAL ICT PROFILES}

As a recent initiative GRIP can be mentioned. GRIP is a "common language" approach, to be used to characterise and analyse existing ICT skills profiles or as a guideline for building new profiles.

GRIP has been developed to meet the demand explained in the preceding paragraphs: how to understand and deal with differences and similarities of profile models and profiles. GRIP does not offer new profiles, it is a method meant for analysis of profile models and profiles. In GRIP the analysis of profile models and profiles is approached in two ways:

a) Analysis of a profile model

A checklist is used to summarise the document and profile model

characteristics. For instance, terminology used, structure of the document, structure of the profiles are recorded (Hacquebard, Dijkxhoorn \& Erkelens 2003).

b) Analysis of a single profile

The content of separate profiles is mapped onto classification schemes for ICT or other disciplines and personal attitude and behaviour.

These mappings are "independent", in the sense that profiles are mapped onto classification schemes which do not belong to any of the profile models.

GRIP maps ICT profiles onto:

- UCSI, Unified Classification Scheme for Informatics, a detailed mapping;

- Other domains (alpha, beta, gamma), a global mapping);

- Personal attitude and behaviour, a detailed mapping.

Our experience is that instruments, like text and linguistic analysis, are needed to perform these tasks. Use of just a yellow marker in documents to identify content, has turned out to be unworkable. 
The outcome of a GRIP analysis of a profile model contains:

- GRIP A: one report about the profile model as a whole;

- GRIP B: as many reports on content as there are profiles in the profile model.

A selection of profile models and profiles has to be made before the analysis is performed. Criterion can be to select profiles belonging to the same category (cell) in the "skills knowledge matrix" It depends on the objectives of the GRIP analysis, which profiles and profile models are to be included. It is obvious that a decision has to be taken about the purpose of the analysis, before applying the GRIP method to profile models and profiles.

Possible purposes are:

- evaluating and benchmarking existing profile models and its profiles;

- comparing job profiles and educational profiles;

- comparing ICT curricula of several IT departments of educational institutes in a region;

- serving as a guideline for revision of existing profiles or for building new profiles.

GRIP can be used for different purposes and in different levels of detail. This approach, originally meant for ICT profiles, seems to be also applicable to a broad range of other domains as the summary and mapping approach can be performed for any profile model or profile, given that classifications schemes for the specific domains of knowledge are available. GRIP can be seen as a first step towards a referential framework. Summaries of analysis outcomes of GRIP will be published on the GRIP site.

\section{CHALLENGE}

Developing a referential framework, that covers the needs of a great variety of users and serves as a protocol for communication about skills and knowledge, requires a strong international commitment, cooperation and effort on research and development, e.g. on text analysis, modelling, taxonomies, structuring and use of unified classification schemes for main domains of knowledge. It is a challenge for international cooperation to gather expertise and initiatives towards developing a referential framework, acknowledged by as many parties as possible, in order to enable the managing of ICT - and other - knowledge and skills profiles.

Such a protocol is a necessary condition for the realisation of the Bucharest declaration, especially for the themes "E-Business: More 
Competitiveness and Better Jobs" and "E-learning and E-Education: Empowering people". A referential framework could be used as a basis and starting point for the development of tools for the management of ICT skills and knowledge in order to realise enhancement of the accumulation of knowledge, the upgrading of skills and access to knowledge. However, the principles of a referential framework are not restricted to the ICT domain, neither are problems about ambiguity of job and educational profiles. This justifies a strong international effort and a professional approach of the development of a referential framework for descriptions of skills and knowledge.

\section{BIOGRAPHIY}

Anneke Hacquebard is General Manager of a Consultancy and Research Bureau for Informatics and Education. She has been active in research on IT Skills models, for example in an initiative by IP-HOB (Informatics Platform Higher Education, Business and Trade), partially founded by the Ministry of Education, Culture and Science, the NGI and the VRI (Dutch Computer Societies). She is one of the originators of the GRIP (Generic Referential ICT Profiles) method. She is working on research on referential frameworks for descriptions of professional quality.

Steven P. Dijkxhoorn is an ICT specialist and is studying Educational Science and Arts at the University of Nijmegen. In developing GRIP, his concern has been the application of text analysis and modelling.

Anita Erkelens B.Sc. graduated from Larenstein University of Professional Education, Velp. She spent several years working on international projects performed by Arcadis Euroconsult and the FAO and was involved in research and vocational training. In developing GRIP, she contributed to the design of classification schemes and modelling. 


\section{APPENDIX}

Table 2. UCSI classification, level 1 and level 2

\begin{tabular}{|c|c|c|c|c|c|c|c|}
\hline 1 & $\begin{array}{l}\text { Computer } \\
\text { systems }\end{array}$ & 2 & $\begin{array}{l}\text { Software } \\
\text { systems }\end{array}$ & 3 & $\begin{array}{l}\text { Information } \\
\text { systems }\end{array}$ & 4 & $\begin{array}{l}\text { Context of } \\
\text { informatics }\end{array}$ \\
\hline 1.1 & $\begin{array}{l}\text { Computer } \\
\text { architecture }\end{array}$ & 2.1 & $\begin{array}{l}\text { Programming } \\
\text { languages }\end{array}$ & 3.1 & $\begin{array}{l}\text { Information } \\
\text { bases (IB) }\end{array}$ & 4.1 & $\begin{array}{l}\text { Management and } \\
\text { informatics }\end{array}$ \\
\hline 1.2 & $\begin{array}{l}\text { Interfacing } \\
\text { and } \\
\text { peripherals }\end{array}$ & 2.2 & $\begin{array}{l}\text { Software } \\
\text { architecture }\end{array}$ & 3.2 & $\begin{array}{l}\text { Information } \\
\text { systems } \\
\text { architecture }\end{array}$ & 4.2 & $\begin{array}{l}\text { Domain specific and } \\
\text { dedicated systems }\end{array}$ \\
\hline 1.3 & $\begin{array}{l}\text { Communica- } \\
\text { tion and } \\
\text { networks }\end{array}$ & 2.3 & $\begin{array}{l}\text { Software } \\
\text { engineering } \\
\text { (SE) }\end{array}$ & 3.3 & $\begin{array}{l}\text { Information } \\
\text { systems } \\
\text { engineering }\end{array}$ & 4.3 & $\begin{array}{l}\text { Informatics operational } \\
\text { environment }\end{array}$ \\
\hline 1.4 & $\begin{array}{l}\text { Operating } \\
\text { systems and } \\
\text { system } \\
\text { software }\end{array}$ & 2.4 & $\begin{array}{l}\text { Artificial } \\
\text { intelligence } \\
\text { (AI) }\end{array}$ & 3.4 & $\begin{array}{l}\text { Interaction } \\
\text { and } \\
\text { Presentation } \\
\text { (IP) }\end{array}$ & 4.4 & Informatics in society \\
\hline 1.5 & Miscellaneous & 2.5 & $\begin{array}{l}\text { Theory of } \\
\text { computing }\end{array}$ & 3.5 & $\begin{array}{l}\text { Theory of } \\
\text { information } \\
\text { systems }\end{array}$ & 4.m & Miscellaneous \\
\hline $1 . \mathrm{m}$ & & $2 . \mathrm{m}$ & Miscellaneous & $3 . \mathrm{m}$ & Miscellancous & & \\
\hline
\end{tabular}

Table 3. Domains of knowledge, level 1 and level 2

\begin{tabular}{llllllll}
\hline A & Alpha sector & B & Beta sector & C & $\begin{array}{l}\text { Gamma } \\
\text { sector }\end{array}$ & I & $\begin{array}{l}\text { Informatics } \\
\text { sector }\end{array}$ \\
\hline A1 & Economics & B1 & $\begin{array}{l}\text { Mathematics, } \\
\text { sciences \& } \\
\text { physics }\end{array}$ & C1 & $\begin{array}{l}\text { Humanities \& } \\
\text { art }\end{array}$ & I1 & Informatics \\
A2 & $\begin{array}{l}\text { Jurisdiction \& } \\
\text { administration }\end{array}$ & B2 & $\begin{array}{l}\text { Engineering \& } \\
\text { technology } \\
\text { Medical }\end{array}$ & C2 & Socio-cultural & I2 & $\begin{array}{l}\text { Business } \\
\text { Informatics }\end{array}$ \\
& B3 & & I3 & $\begin{array}{l}\text { Medical } \\
\text { Informatics } \\
\text { Technical } \\
\text { Informatics } \\
\text { Infial } \\
\text { Informatics }\end{array}$ \\
\hline
\end{tabular}

Table 4. Domains of personal behavior and attitude, level 1 and level 2

\begin{tabular}{|c|c|c|c|c|c|c|c|}
\hline $\mathrm{D}$ & Rational & $\mathrm{F}$ & Performance & $\mathrm{H}$ & Attitude & $\mathrm{O}$ & Development \\
\hline$\overline{\mathrm{Da}}$ & Analytical & $\overline{F l}$ & Executive & $\mathrm{Hb}$ & $\begin{array}{l}\text { Professional or } \\
\text { vocational }\end{array}$ & $\mathrm{Oa}$ & Ambition \\
\hline Dc & Conceptual & $\mathrm{Ft}$ & Team & Hp & Personal & $\mathrm{Oe}$ & Experience \\
\hline Do & Other & $\mathrm{Fz}$ & Individual & & & $\mathrm{O} 1$ & $\begin{array}{l}\text { Intellectual } \\
\text { faculties(1), } \\
\text { learning } \\
\text { potential }\end{array}$ \\
\hline
\end{tabular}




\section{REFERENCES}

Hacquebard, A., S. Dijkxhoorn \& A. Erkelens (2003) GRIP: A different outlook on profiles, Overview. Adviesbureau voor Informatica en Onderwijs Hacquebard bv, Hummelo. [http://www.grip-project.nl].

IFIP OECD WITSA Joint Working Conference Meeting Global IT Skills Needs - the Role of Professionalism (October 25th - 27th 2002) Summary proceedings, Woking, Surrey, United Kingdom. [http://www.globalitskills.org/proceedings.pdf]

Mulder, F. \& T. J. van Weert (2000) Informatics Curriculum Framework 2000 for higher education [ICF-2000], UNESCO, Paris. [http://www.ifip.or.at/pdf/ICF2001.pdf]

The Bucharest Declaration (2002) Towards an Information Society: Principles, Strategy and Priorities for Action. Bucharest Pan-European Conference in Preparation of the World Summit on the Information Society: 9 November 2002. [http://www.wsisromania.ro/menu/home/Documents/declaration.html] 